\title{
A New Titanopteran from Southwestern Korean Peninsula: The Triassic Age of the Nampo Group and its Tectonic Implications
}

Tae-Yoon S. Park ( $\square$ typark@kopri.re.kr)

Korea Polar Research Institute

Do-Yoon Kim

Seoul National University

Gi-Soo Nam

Gongju National University of Education

Mirinae Lee

Korea Polar Research Institute

\section{Research Article}

Keywords: Triassic, Titanoptera, Nampo Group, tectonics, southwestern Korean Peninsula, Cathaysia

Posted Date: July 30th, 2021

DOl: https://doi.org/10.21203/rs.3.rs-760793/v1

License: (c) (i) This work is licensed under a Creative Commons Attribution 4.0 International License. Read Full License 


\section{Abstract}

Titanopterans are well-known as giant predatory insects in the Triassic, but not only their rare occurrences have been limited to Central Asia and Australia, but also their phylogenetic affinity remains unresolved. The age of the nonmarine sequences of the Nampo Group at the southwestern Korean Peninsula is unclear, and the tectonic affinity of the surrounding area is contentions. Here we report a new titanopteran Magnatitan jongheoni gen. et sp. nov. the Amisan Formation, Nampo Group, which marks the first discovery of the titanopteran fossil from outside Central Asia and Australia, presenting a possible circumTethys Ocean distribution, at least, during the Late Triassic. The new fossil shows a clearly divided CuPb, which will help understand the evolution of titanopterans in the future. Moreover, the occurrence of a titanopteran finally confirms the Late Triassic age of the Nampo Group. In China, similar Late Triassic non-marine sequences are widespread in the Cathaysia Block, in which various geological features similar to those in the southwestern Korean Peninsula, such as a Paleozoic magmatism and an eclogite facies with Neoproterozoic protoliths, have been recently documented as in the southeastern Korean Peninsula. Such similarities may suggest a close tectonic affinity between the northeastern Cathaysia Block and the southwestern Korean Peninsula.

\section{Introduction}

Titanoptera is an iconic insect group of the Triassic. The prominently large size (a wingspan of up to 400 $\mathrm{mm}$ is documented by Gigatitan vulgaris ${ }^{1}$ ), and the raptorial forelegs equipped with stout spines, make them the most impressive predatorial insects of the Triassic ${ }^{1,2}$. Both sexes seemed to have had 'sound apparatus' in forewings, which may have produced deep and resonant acoustic signals in Triassic forests $^{2}$ (but see ref [3]). Despite the fame, however, their phylogenetic affinity remains unstable. Although titanopterans are often considered closely-related to orthopterans, no consensus has been made on their phylogenetic position. Titanoptera was treated as a separate order closely related to Orthoptera ${ }^{1,4}$. It was argued that titanopterans originated from the Permian orthopteran Tcholmanvissiidae ${ }^{5}$, rendering this family paraphyletic ${ }^{1}$. Subsequently, it was suggested the Carboniferous protorthopteran family Geraridae $^{6}$ as a sister group of Titanoptera ${ }^{7}$. In a reinvestigation of the wing veins Order Titanoptera was derived from the Tchomanvissidae ${ }^{8}$. Recently, however, the close relationship between the Tchomanvissidae and Titanoptera was questioned ${ }^{9}$ (but see ref [10]). The incomplete understanding of its affinity is mainly due to the small number of fossils with limited paleogeographic occurrences; to date, all titanopteran fossils have been known only from Central Asia and Australia ${ }^{1,11-13}$.

The complicated suite of geologic features in the Korean Peninsula has led to a variety of interpretations on the tectonic processes which have formed them. Especially regarding the collision of the Sino-Korean (North China) Craton and South China Craton at around the Permo-Triassic, several disparate hypotheses have been put forward for the tectonic affinity and the movement of the Korean Peninsula ${ }^{14-20}$. Disagreements derives not only from the way of interpreting the various geological data, but also from not-well constrained ages of several sedimentary basins which developed under the tectonic framework 
during the Mesozoic. The Nampo Group in the Chungnam Basin is situated at southwestern part of the Korean Peninsula (western Gyeonggi Massif), and consists of non-marine fluvial, alluvial, and lacustrine successions $^{21,22}$. Although it is one of the largest Mesozoic basins in Korea, its depositional age has remained controversial. Paleontological evidence such as plant and choncostracan fossils ${ }^{23-25}$ have suggested Late Triassic to Early Jurassic for the age ${ }^{23-25}$, which has led to the interpretations that the successions formed in post-collisional extensional basins ${ }^{26-28}$. In contrast, radiometric dating from a volcanic deposit provided Jurassic ages (172 Ma) for the deposition of the Nampo Group ${ }^{29,30}$, which has called for the Jurassic Daebo orogeny for the basin formation ${ }^{21,30-32}$. In the most recent geological map of the Korea the Nampo Group was also regarded as coeval to other non-marine deposits of small-scale piggyback basins in other part of the Korean Peninsula ${ }^{33}$, which were formed by the Daebo orogeny. Recently, the formation process of the volcanics was distinguished from the deposition of the Nampo Group $^{27,34}$, and subsequently it was suggested that the Chungnam Basin further subsided at Early to Middle Jurassic to accommodate the volcanic deposits ${ }^{26,28}$.

This study reports a new titanopteran genus from the Amisan Formation, Nampo Group, Chungnam Basin, Korea, which is the first discovery of the titanopteran fossil from outside Central Asia and Australia, contributing to better understanding of the morphological diversity and paleogeographic occurrence of this giant insect group. More importantly, since titanopterans were wiped out at the endTriassic mass extinction, the discovery of the new titanopteran genus finally help confirm the Triassic age of the Nampo Group. With the recent discoveries of various geological features from the southwestern Korean Peninsula and the Cathaysia Block in South China, the Triassic age of the Nampo Group could provide an important insight to the tectonic affinity of this area.

\section{Geological Setting}

Since the original establishment by Kobayashi ${ }^{35}$, the threefold division of the Precambrian basement of the Korean Peninsula (i.e. Nangrim, Gyeonggi, and Yeongnam massifs) has been widely adopted, and they are separated by two supracrustal belts, the Imjingang and the Okcheon belts ${ }^{36}$ (Fig. 1). The Daedong Supergroup refers to the Triassic to Jurassic deposits in small-scale non-marine basins in the Korean Peninsula, including the Chungnam Basin. However, since the basins that formed during the Songrim orogeny which was caused by the Permo-Triassic collision of the Sino-Korean Craton and the South China Craton, should be distinguished from those formed by the subduction-related Jurassic Daebo orogeny, the concept and definition of the Daedong Supergroup requires emendation ${ }^{36}$.

The outcrops of the Chungnam Basin are distributed in three closely-situated areas, the Ocheon, Oseosan, and Seongju areas, from west to east (Fig. 1), which even have been recognized as isolated sediment fills in subbasins ${ }^{21}$. The Chungnam Basin includes the Nampo Group and the mid-Jurassic Oseosan Volcanic Complex which unconformably overlies the Nampo Group in the Oseosan area ${ }^{27}$. The fluvial, alluvial, and lacustrine successions of the Nampo Group of the Chungnam Basin consist of five formations; the Hajo, Amisan, Jogyeri, Baegunsa, and Seongjuri formations, in ascending order $21,37,38$. The Hajo, Jogyeri, and 
Seongjuri formations are dominated by conglomerate and sandstone facies, while the fossiliferous Amisan and the Baegunsa formations are comprised of coal-bearing shale and sandstone, with minor amount of conglomerates in the lower part of the Baegunsa Formation ${ }^{38}$. The Nampo Group is unconformably overlain by the Early to Middle Jurassic Oseosan Volcanic Complex, which consists of light gray to gray tuff and lapilli tuff, overlain by thick tuffaceous sedimentary rocks of gray to dark gray shale, sandstone, and conglomerate ${ }^{27}$. The basement rocks of the Chungnam basin is largely of the Neoproterozoic and Paleozoic metamorphic rocks (the Wolhyeonri complex) in the west of the Oseosan area, while the Paleoproterozoic granite gneiss is prevalent to the east of the Oseosan area ${ }^{33}$ (Fig. 1). Various hypotheses have been proposed for the development of the Chungnam Basin, under the view that the Chungnam Basin is part of the Daedong Supergroup, which include development of half-grabens or pull-apart basin from the late stage of the Songrim orogeny ${ }^{39}$, deposition in syn-orogenic (Songrim orogeny) piggyback basins ${ }^{16}$, and syntectonic deposition during the early stages of the Daebo orogeny ${ }^{30}$. Subsequent researchers ${ }^{21}$ considered the "subbasins" of the Chungnam Basin as piggyback basins formed during the Daebo orogeny ${ }^{21}$. Most recently, a basin development model of post-collisional extensional deformation at the Late Triassic was proposed 26,28 , which is based on the assumption that an eastward extension of the Sulu collisional belt runs through this area ${ }^{17,19}$.

The Amisan formation is known to be up to $1,000 \mathrm{~m}$ thick, and consists of the lower sandstone units, the lower shale unit, the middle sandstone units, the middle shale unit, and the upper sandstone unit ${ }^{38}$. Diverse fossils have been documented from the Amisan Formation, including plants ${ }^{40-45}$, bivalves ${ }^{46}$, conchostracans ${ }^{25}$, insects ${ }^{47,48}$, and fishes ${ }^{49}$. Of them, plant and conchostracan fossils have been used for age dating for the Amisan Formation. The Late Triassic age was suggested, based on the plant fossil assemblages ${ }^{45}$, but most of the genera in the subsequent paleobotanical researches appeared to have ranges up to Lower Jurassic or even up to Cretaceous ${ }^{24,41,43,44,50-52}$. The conchostracan species of the formation were also considered to be Triassic in age, based on poorly-preserved specimens ${ }^{25}$, but the Mesozoic occurrence of the bivalve genus Margaritifera, the only known bivalve genus from the Amisan Formation, was then known to be restricted to post-Triassic ${ }^{46}$. In addition, the Jurassic radiometric ages

of the Nampo Group ${ }^{29,30}$ have questioned the Triassic age from the paleontological evidence, calling for more convincing evidence ${ }^{25}$.

\section{Material And Methods}

A single forewing with well-preserved venations is discovered from the middle shale unit of the Amisan formation exposed in the Myeongcheon section (Fig. 1). The sample was photographed submerged in water, with a Canon EOS 60D using a Canon EF $100 \mathrm{~mm}$ f/2.8 USM macro lens. High-angle lighting was used for the maximal reflective image of the specimen. Images were cropped and enhanced by means of contrast and brightness in Adobe Photoshope CS6. For the relief-enhanced images, raw images for polynomial texture mapping were acquired by a self-crafted system which permits lighting from 50 different directions and the same Canon EOS60 camera setting mentioned above. The specimen was 
white-coated with magnesium oxide for this process. In order to enhance surface details of the fossil, 50 images were taken and converted into a PTM format file which was then run in RTI Viewer software which is freely downloadable at http://culturalheritageimaging.org/What_We_Offer/Downloads/.

The specimen was also gold-coated using a Cressington 108 Auto sputter coater with $10 \mathrm{~mA}$ for $80 \mathrm{~s}$. A field-emission electron probe microanalyzer (JEOL JXA-8530F) and a low vacuum field emission scanning electron microscope (JEOL JSM-7200F-LV) at the Korea Polar Research Institute were used to acquire $\mathrm{X}$-ray elemental maps and surface analysis. $\mathrm{X}$-ray elemental maps for $\mathrm{C}, \mathrm{N}, \mathrm{O}, \mathrm{Mg}, \mathrm{Al}, \mathrm{Si}, \mathrm{P}, \mathrm{S}, \mathrm{Cl}, \mathrm{K}$, $\mathrm{Ca}, \mathrm{Ti}, \mathrm{Mn}, \mathrm{Fe}, \mathrm{Ni}, \mathrm{Cu}, \mathrm{Zn}$, and $\mathrm{Ba}$ were obtained using five wavelength dispersive spectrometry (WDS) and nineteen energy dispersive spectrometry (EDS), with an acceleration voltage of $20 \mathrm{kV}$, beam current of $200 \mathrm{nA}$, beam size of $13 \mu \mathrm{m}$, dwell time of $10 \mathrm{~ms}$, and step size of $13 \mu \mathrm{m}$. Raw data of X-ray elemental maps were imported and processed for brightness and contrast by Image $\mathrm{J}^{53}$. Qualitative point data was generated from the gold-coated specimen using an accelerating voltage of $5 \mathrm{kV}$ and probe current of 10 nA by EDS equipped at the low vacuum field emission scanning electron microscope.

General wing venation nomenclature follows ref [54], which was also verified by a subsequent research ${ }^{55}$. Interpretation of titanopteran specific wing venation pattern follows ${ }^{8}$. Anatomical abbreviations are as follows. AA1: first anal veins; AA2: second anal veins; CuA: cubitus anterior, CuP: cubitus posterior; CuPa: anterior branch of CuP; CuPaa: anterior branch of CuPa; CuPaa: the first posterior branch of CuPaa; $\mathrm{CuPaa}^{*}$ : the second posterior branch of $\mathrm{CuPaa}$; $\mathrm{CuPaa}^{\circ}$ : the anterior stem of $\mathrm{CuPaa} ; \mathrm{CuPa}$; posterior branch of $\mathrm{CuPa}$; CuPb: posterior branch of $\mathrm{CuP}$; CuPba: anterior branch of $\mathrm{CuPb}$; $\mathrm{CuPb}$ : posterior branch of $\mathrm{CuPb}$; M: median vein; MA: median anterior, MP: median posterior; R: radius; RA: radius anterior; RP: radius posterior; ScA: subcostal anterior; ScP: subcostal posterior.

\section{Systematic Paleontology}

Superorder Archaeorthoptera Béthoux \& Nel, 2002

Suborder Titanoptera Sharov, 1968

family Paratitanidae Sharov, 1968

Magnatitan jongheoni gen. et sp. nov.

\subsection{Etymology}

The generic name is derived from the Latin 'Magna,' referring to its large size, and the general name of the group 'titan'. The species name was designated in honor of the collector of the specimen, Prof. Jongheon Kim (Kongju National University) who has made significant paleontological contributions for the Nampo Group over the last thirty years.

\subsection{Holotype}


GNUE112001, an almost complete left forewing. The specimen is housed in the Gongju National University of Education.

\subsection{Type locality and horizon}

The middle shale unit of the Amisan Formation, Upper Triassic, Myeongcheon Section, Seongju-myeon, Boryeong City, Chungcheongnam-do, Republic of Korea.

\subsection{Diagnosis}

ScP strong; RA and RP are divided near to distal half of the wing, CuPb divided into CuPba and $\mathrm{CuPb} \beta$. ScP with many branches and dichotomously ramified at distal part; RA extends one branch at distal part; division of MA and MP close to fusion of CuA and CuPaa; MP ramified into two branches near to reseparated CuPaa from CuA. area between CUA to posterior wing margin widened.

\subsection{Description}

Forewing large with pointed apex, anterior margin anteriorly bowed, posterior margin posteriorly bowed, preserved length $57.3 \mathrm{~mm}$, width $19.0 \mathrm{~mm}$; distal part of ScA preserved, weak; area between ScA to anterior wing margin narrow; ScP long and strong, anteriorly pectinate with many branches and dichotomously ramified at distal part; R concave; RA and RP are divided near the distal half of the wing; RA extends one branch weakly at distal part; separating $M$ and CuA preserved, nearby M divided into MA and MP; M gently twisted, divided into MA1 and MA2 at more distal than dividing RA and RP; free part of basal M short; MP concave, dichotomously ramified between dividing R and dividing MA; area between MA and MP wide with dense and sturdy cross-veins; CuA seperated from M, fused with CuPaa ${ }^{\circ}$, free part of basal CuA short; CuA + CuPaa ${ }^{\circ}$ long, gently concave; branch of CuPaa ${ }^{\circ}+\mathrm{CuPaa}^{*}$ long, posteriorly pectinated with $\mathrm{CuPa}^{\star}$ and $\mathrm{CuPaa}^{\circ} ; \mathrm{CuPa}$ seperated from CuPaa near the widest area between MA and MP; fused CuPaa + CuPa $\beta+\mathrm{CuPb}$ long; CuPb separated from CuPaa + CuPaß, divided into CuPba and $\mathrm{CuPb} \beta$, basal of $\mathrm{CuPb}$ short; fused $\mathrm{CuPaa} \cdot+\mathrm{CuPa} \beta$ longer than separated free CuPa $\beta$; preserved $\mathrm{AA} 1$ and AA2 long without any branch; cross-veins dense, long, and simple, but organized networks present near the margin.

\subsection{Remarks}

\subsubsection{Titanopteran and the Late Triassic paleoecology of the Nampo Group}

Compared to the large number of plant fossils (more than twenty species reported), only a small number of invertebrate fossils have been documented from the Nampo Group: i.e., a single species of bivalve ${ }^{46}$, four species of conchostracans ${ }^{25}$, and two species of insects ${ }^{47,48}$. The occurrence of the titanopteran fossil from the Amisan Formation, therefore, adds a new component to the Late Triassic ecology of the 
Nampo Group. Given its large size, Magnatitan must have played an important role in the food web as daunting predators on insects, invertebrates, and possibly small tetraopds, such as amphibians (Fig. 3).

\subsubsection{Familial assignment and presence of divided CuPb}

The two most important synapomorphies of titanopterans are $\mathrm{CuPaa}+\mathrm{CuPa} \beta$ and $\mathrm{CuPb}$ having the same point of origin ${ }^{8}$, and the presence of strongly-developed cross-veins between MA and MP, both of which are well-recognized in the new specimen in this study. The Family Paratitanidae is characterized by the division of RA and RP near the distal half of the wing, and previously included two genera Paratitan ${ }^{1}$ from the Lower-Middle Triassic of Kyrgyzstan and Minititan ${ }^{56}$ from the Middle-Upper Triassic of Kyrgyzstan. The location of the RA and RP division in the forewing justifies the assignment of the Late Triassic Magnatitan in this study into the Paratitatnidae. However, Magnatitan differs from Paratitan and Minititan in having a significantly large size and the division of $\mathrm{CuPb}$ into $\mathrm{CuPba}$ and $\mathrm{CuPb} \beta$.

It was argued that the divided $\mathrm{CuPb}$ is present in some members of Archaeorthoptera, Panorthoptera and Titanoptera ${ }^{9}$, considering this feature in those groups as results of convergent evolution, questioning the close relationship between the Titanoptera and the orthpoteran Family Tcholmanvissidae. In contrast, a subsequent research reinterpreted the wing vein homology of those groups and proposed the divided $\mathrm{CuPb}$ was not present in titanopterans, reinstating the close relationship of the Titanoptera and the Tcholmanvissidae of the Archaeorthoptera ${ }^{10}$. One of the significant features of Magnatitan jongheoni gen. et sp. nov. is the presence of divided $\mathrm{CuPb}$, while sufficing the criteria for titanopterans. The new fossil in this study, therefore, will provide a new data for future discussion on the homology of orthopteran wings.

\subsubsection{Mineralogy of the fossil}

In recent paleontological researches using WDS analyses on fossiliferous shale, various body structures, such as brains in Cambrian stem-arthropod fossils ${ }^{57}$, and wing venations and a subgenetal plate in Cretaceous elcanid orthopteran fossils ${ }^{58}$, were highlighted in the carbon elemental maps by different carbon concentrations, indicating that the fossils were preserved as thin carbonaceous film on dark shale. The mineralogy of the new titanopteran fossil from the Amisan Formation in this study, however, seems different from those in the previous studies. Carbon distribution on the fossil surface is scarce (Fig. 4C), and there is less silicon (Fig. 4J), compared to the matrix. Instead, enriched on the fossil surface are aluminum and potassium (Fig. $4 \mathrm{~K}$ and $\mathrm{L}$ ).

Along the thick wing veins, dendrite-like overgrowth textures are present (Fig. 4A). Qualitative point analysis by EDS equipped at the low vacuum field emission scanning electron microscope, however, has shown that the total EDS spectra of the wing membrane area, the wing veins, and the dendrite-like textures are comparable to each other. Similar results have been acquired from a XRD microstructural analysis applied to the wing and the matrix rocks. In the elemental maps, a slight amount of magnesium and oxygen is present along the thick veins (Fig. 4E and I), while traces of titanium are recognized along 
the dendrite-like overgrowth (Fig. 4F). There are prominent absence of iron, calcium, and potassium along the dendrite-like overgrowth (Fig. 4D, G. and L). At present, however, the mineralogy of the fossil is not clearly identified, requiring further research.

\section{Discussion}

\subsection{First documentation of titanopteran in East Asia}

Previously, the occurrences of titanopterans have been restricted to Central Asia including the Triassic Madygen Formation of Kyrgyzstan, the Permian of Tyulgan District of Russia, the Triassic near the Lake Wivenhoe, Queensland, Austrailia, and the Middle Triassic of New South Wales, Australia. A recent report documented a fragmentary forewing of titanopteran from the Carboniferous of France ${ }^{3}$, but further investigations would merit, given the much earlier age and the incomplete preservation. In the Triassic paleogeography, Central Asia was located to the north of the Tethys Ocean, while Australia was located to the south of the Ocean, and the two areas were connected by the regions spreading along the western margin of the Tethys Ocean, such as Europe, northern Africa, Arabia, and India ${ }^{59}$. This implies that titanopterans may have also inhabited in those regions along the western margin of the Tethys Ocean (Fig. 5). By the Late Triassic, the East Asian plates, including the Sino-Korean, South China, and Indochina cratons were accreted to form a large continental crust, located to the east of the Tethys Ocean ${ }^{59}$ (Fig. 5). Accordingly, the new discovery of titanopteran fossil from Korea may suggest a circum-Tethys Ocean distribution of titanopterans, at least in the Late Triassic. The possible widespread distribution of titanopterans implies a critical role that this giant insect predators may have played in the Triassic terrestrial ecology. Future investigations on the Triassic nonmarine deposits in the circum-Tethys Ocean regions may lead to new discoveries of titanopterans.

\subsection{Triassic age of the Nampo Group and development of the Chungnam basin}

Titanopterans are known as representative predatorial insects of the Triassic ${ }^{2}$, although an occurrence from the Upper Permian has been documented ${ }^{56}$. The occurrence of a titanopteran in this study, therefore, evinces the Triassic age for the Amisan Formation. Previously, the Family Paratitanidae to which the new genus Magnatitan belongs, composed of two genera, the Lower to Middle Triassic Paratitan ${ }^{1}$ and the Middle to Upper Triassic Minititan ${ }^{56}$. The worldwide "coal accumulation gap" interval is known from the Lower Triassic to the Middle Triassic ${ }^{60-62}$, whose cause is still debated (see ref [62]). The frequent occurrences of coal-bearing layers in the Amisan Formation and the Baegunsa Formation, therefore, constrains the age of these formations as post-Middle Triassic. This result confirms the Late Triassic age for the Amisan Formation proposed from the previous paleontological researches ${ }^{25,45}$. In this regard, the occurrences of the plant fossil genera Lobatannularia and Sphenophyllum from the Baegunsa Formation, which overlies the Amisan and the Jogyeri formations, may suggest the Upper Triassic spanning up to the Baegunsa Formation. It was even regarded the two genera as relic components from the Late 
Paleozoic Cathaysian flora of East Asia ${ }^{24,25}$. If so, the uppermost unit of the Nampo Group, the Seongjuri Formation remains to be the only unit with a possibility of stretching up into the Lower Jurassic. The youngest detrital zircon data from the Seongjuri Formation shows a range from 197 to $175 \mathrm{Ma}^{26}$, supporting the possibility.

The Late Triassic age of the Amisan Formation (and probably of the Baegunsa Formation) confirmed in this study decouples the development of the Chungnam Basin from the Jurassic Daebo orogeny, which initiated at around $187 \mathrm{Ma}^{63}$ by the northwestward subduction of the Paleo-Pacific (Izanagi) plate on the Asiatic margin. The Daebo orogeny resulted in northeast-southwest (NE-SW) trending regional folds and thrusts in the "Okcheon belt" of the Korean Peninsula ${ }^{63,64}$. The thrusts formed during this event led to the development of syntectonic NE-SW trending Jurassic piggyback basins, such as the Bansong Group. The "subbasin"-style developmental model of the Chungnam Basin on an assumption that they were piggyback basins formed by the Daebo orogeny ${ }^{21}$. Moreover, the misinterpretation of the Oseosan Volcanic Complex as a conformable stratigraphic unit underlying the Amisan Formation in the Oseosan area led to the notion that each subbasin has different stratal thickness, stratigraphy and lithology. Now the Oseosan Volcanic Complex is a stratigraphically distinguished from the Nampo Group ${ }^{26-28}$, and the development of the basin predated the Jurassic Daebo orogeny. The "subbasin"-style developmental model for the Chungnam Basin, therefore, turns out to be implausible.

The geological structures in this area indicate that the Chungnam Basin was developed under an extensional regime ${ }^{34}$. The Chungnam basin was considered as one of the post-collisional extensional basins ${ }^{27,28}$, based on the assumption that the western Gyeonggi massif is an eastward extension of the Qinling-Dabie-Sulu collision belt formed during the Permo-Triassic collision of the Sino-Korean Craton and the South China Craton ${ }^{17,18}$. In addition, it was conjectured that the Chungnam Basin further subsided at the Early to Middle Jurassic to accommodate the Oseosan Volcanic Complex ${ }^{26,28}$. However, not only Late Triassic post-collisional extensional basin is absent in the Qingling-Dabie-Sulu belt, but also recent geological evidence points toward that the western Gyeonggi massif is not an extended collision belt (see below). The only Late Triassic basin around the collisional belt in China is the Nanzhao basin at the northern margin of the Qinling Orogenic Belt, which formed as a wedge top depozone of a foreland basin system ${ }^{65}$.

At present, it is inferred that the Chungnam Basin was formed under an extensional regime during the Late Triassic. Being closely situated to the Okchen Belt, the Chungnam Basin was subsequently affected by the Daebo orogeny, resulting in the NE-SW trending thrusts in the area (Fig. 1), which involved shortening of both the sedimentary rocks and the basement ${ }^{28}$. The distribution of the Oseosan Volcanic Complex is elongated in NE-SW trend, and is bordered by a NE-SW trending thrust (the Jangsan Fault) to the southeast (Fig. 1). Because NE-SW trending folds and thrusts are typical features formed by the Jurassic Daebo Orogeny in the Okcheon Belt, we interpret that the Oseosan Volcanic Complex was deposited in a piggyback basin or a small-scale foreland basin formed under the influence of the Daebo orogeny. The age of the Oseosan Volcanic Complex (178 to $172 \mathrm{Ma})^{27}$ also corresponds well with the 
time range of the Daebo orogeny. The small-scale NE-SW trending imbricated sheets within the Oseosan Volcanic Complex (see ref [28]) may have also formed during the subsequent phase of the orogeny. Although the deposits of the basin are now distributed in three currently-isolated areas (the Ocheon, Oseosan, and Seongju areas) (Fig. 1), given the same stratigraphic sequences occurring in all areas, the Chungnam Basin must have developed as a single basin.

\subsection{Tectonic affinity of the southwestern Korean Peninsula}

In the diverse hypotheses on the tectonic affinity of the Korean Peninsula during the Permo-Triassic collision of the Sino-Korean Craton the South China Craton, the southwestern part of the Korean Peninsula (western Gyeonggi Massif) has been considered as part of the South China Craton ${ }^{15,16,36}$, part of the North China Craton ${ }^{19,20}$; or an eastward extension of the Sulu collision belt ${ }^{17,18}$. Under the framework of the tectonic evolution of East Asia the presence of the Late Triassic non-marine sequence, confirmed in this study, could provide new insight for the tectonic affinity of the southwestern Korean Peninsula. The Triassic sedimentary rocks are widely distributed in the North China Block and South China Craton ${ }^{66}$. However, those of North China Craton developed in a large-scale basin in the central part, and is stratigraphically continued from the Late Paleozoic, while those of the Yangtze Subregion of South China represents marine lagoonal facies from the Lower to Upper Triassic ${ }^{66}$. Interestingly, the Triassic of the Southeast Subregion of South China, which mainly includes the northeastern part of the Cathyasia Block, consists of the Upper Series of non-marine facies developed in small isolated basins ${ }^{61,66-69}$ (Fig. 6), presenting similar depositional environments to the Nampo Group. Given the northeast-trending border of the northeastern Cathaysia Block (Fig. 6), this similarity may suggest a close tectonic affinity between the northeastern Cathaysia Block and the southwestern Korean Peninsula.

The link between the northeastern Cathaysia Block and the southwest Korean Peninsula can be corroborated by the recent petrological discoveries, which show remarkable similarities between the two regions. For the last couple of decades, various geological features, mostly unique in the Korean Peninsula, have been documented in the Wolhyeonri Complex, which unconformably underlies the Nampo Group in the Ocheon and Oseosan areas of (Fig. 1). The Wolhyeonri Complex includes serpentinized ultra mafic rocks, migmatitic gneiss, and amphibolites with garnet granulite relics, retrograded from an eclogite ${ }^{70}$. The mafic intrusive body with eclogite relics and marbles occur as a lensshaped exposure within granitic gneiss ${ }^{17}$. The eclogites in this area show a metamorphic age of $\sim 230$ $\mathrm{Ma}$ (Triassic), with $\sim 880 \mathrm{Ma}$ (Neoproterozoic) of the protolith age $\mathrm{e}^{17,70}$, and have been treated as evidence of an extension of the Permo-collisional belt into this area ${ }^{17,18}$. More recently, the early-middle Paleozoic orogenic signals were reported from the Wolhyeonri Complex ${ }^{71-73}$, which was interpreted as evidence of a continental arc-magmatism ${ }^{73}$, or of subduction and the following collisional process of a microcontinent ${ }^{71}$.

The Precambrian rocks and their subsequent alteration within the Cathaysia Block are well represented in the Badu Complex and the Chencai Complex ${ }^{74,75}$, located in the northeastern Cathaysia Block (Fig. 6). In 
these areas, garnet-bearing amphibolites frequently occur with mafic rocks ${ }^{74-76}$. Recently, retrograded eclogite and mafic granulite from the Badu Complex was documented ${ }^{74}$, whose metamorphic age is 234 $\mathrm{Ma}$ (Triassic), with $997 \mathrm{Ma}$ (Neoproterozoic) for the protolith age of the mafic granulite, which are comparable to the metamorphic and the protolith ages of the eclogites in the Wolhyeonri Complex. The Chencai Complex presents various high-grade metamorphic rocks including migmatitic gneiss and marble, and various mafic intrusive rocks, which mainly shows the Neoproterozoic and early to middle Paleozoic orogenic signals ${ }^{77-80}$. The northeastern Cathaysia Block was further affected by the Triassic orogeny, which may have been attributed to the collisions of South China with North China and Indochina ${ }^{81}$. Notably, the early-middle Paleozoic event in South China is known as the Kwangsian (WuyiYunkai) orogeny, which formed a wide compressive regime in the Cathaysia Block and the southern part of the Yangtze Block ${ }^{82,83}$. This early-middle Paleozoic Kwangsian orogeny is closely comparable to the early-middle Paleozoic orogenic signals from the Wolhyeonri Complex, as recently suggested ${ }^{84}$. Interestingly, the late Triassic Wuzao Formation, a non-marine sequence with minor amount of coal measures, unconformably overlies the Chencai Group in the Chencai Complex ${ }^{85}$ (Fig. 6), assuming a similar geological appearance to the Nampo Group, which unconformably overlies the metamorphic and the mafic intrusive rocks in the Wolhyeonri Complex (Fig. 1).

To sum up, the common occurrence of Triassic eclogites with Neoproterozoic protolith age, similar lithologic components, and the similar early-middle Paleozoic orogenic signals, point toward the tectonic linkage between the northeastern Cathaysia Block and the southwestern Korean Peninsula (Fig. 6). Taken together with the common occurrences of the non-marine Late Triassic sequences, we propose that the southwestern Korean Peninsula represents the eastward extension of the Cathaysia Block. This tectonic linkage offers a new insight for interpretation of debated geological features in the Korean Peninsula. The early-middle Paleozoic orogenic signals in the Wolhyeonri Complex can be viewed in connection with the Kwangsian orogeny in the Cathaysia Block, whose nature is still debated ${ }^{86}$, although a large-scale basin inversion has been proposed ${ }^{82}$. More importantly, there are frequent Early to Late Triassic granite intrusions in southern South China Craton ${ }^{87}$. Their exposures in the northeastern Cathaysia are mostly covered by intensive deposition of the Cretaceous volcanics (as in the southern part of the Korean Peninsula), but not rare (see ref [88]). For the petrogenesis and tectonic setting of the Triassic granites in the South China Block, the model involving the collision with the Indochina Block is often invoked for those in southwestern Cathaysia Block ${ }^{89-92}$, while the A-type granites in the northeastern Cathaysia have been related to the subduction of the Paleo-Pacific plate ${ }^{93-96}$. A recent research proposed a flat slab subduction model for the Indosinian orogenic event in the Cathaysia Block, which involved a Middle Triassic exhumation event ${ }^{97}$. The Triassic intrusive rocks of the Korean Peninsula are widespread ${ }^{98-100,}$ and have largely been interpreted as post-collisional magmatism ${ }^{100-102}$. The Cathaysia-affinity of the southwestern Korean Peninsula proposed in this study indicates a close paleogeographical proximity of the Korean Peninsula to the Cathaysia Block after the Permo-Triassic collision. The petrogenesis of the Triassic plutons in the Korean peninsula can, therefore, be interpreted in conjunction with the Triassic magmatism in the Cathaysia Block ${ }^{103}$. 


\section{Declarations}

\section{Competing Interest}

The authors declare that they have no known competing interests or personal relationships that could have appeared to influence the work reported in this paper.

\section{Acknowledgements}

We are grateful to reviewers and the editor. Yeongju Oh helped us in the field.

\section{Author contributions}

T.Y.S.P. and D.Y.K. designed concept of the study and performed methodology,writingoriginaldraftpreparation. T.Y.S.P. reviewed andedited the manuscript. T.Y.S.P. supervised the project and funding acquisition. G.S.N. curated thefossil data and provided theresources for this study.M.L. employed software andformal analysis. All authors approved the manuscript.

\section{Funding}

This project was financially supported by KOPRI project (PE21060).

\section{References}

1 Sharov, A. Phylogeny of Orthoptera insects. Transactions of the Paleontological Institute, Academy of Science of the USSR118, 3-208 (1968).

2 Grimaldi, D. \& Engel, M. S. Evolution of the Insects. (Cambridge University Press, 2005).

3 Schubnel, T. et al. Sound vs. light: wing-based communication in Carboniferous insects. Comm. Biol.4, 1-11 (2021).

4 Crampton, G. The phylogeny and classification of insects. J. Entomol. Zool.16, 33-47 (1924).

5 Zalessky, M. O novykh nacekomykh iz permiskikh otlozhenij bassejnov rek Kamy, Vyatki i Beloj. Trudy Obcsh. Est.Kazan. Univ.52, 1-30 (1929).

6 Scudder, S. H. Palaeodictyoptera; or the affinities and classification of Paleozoic Hexapoda. (1885).

7 Gorochov, A. On the higher classification of the Polyneoptera. Acta Geol. Leopoldensia24, 11 (2001).

8 Béthoux, O. Cladotypic taxonomy applied: titanopterans are orthopterans. Arthropod Syst. Phylo.65, 135-156 (2007). 
9 Huang, D., Schubnel, T. \& Nel, A. A new middle Permian orthopteran family questions the position of the Order Titanoptera (Archaeorthoptera: Orthoptera). J.18, 1217-1222 (2020).

10 Bethoux, 0 . The nesting of titanopteran insects within tcholmanvissiids reassured and the earliest caeliferan identified: a reply to Huang et al.(2020). J. Syst. Palaeontol. 18, 1657-1668 (2020).

11 Tillyard, R. in Proceedings of the Linnean Society of New South Wales. 374-377.

12 Riek, E. Further triassic Insects from Brookvale, NSW (orders Orthoptera Saltatoria, Protorthoptera, Perlaria). Rec. Aus. Mus.23, 162-168 (1954).

13 Jell, P. \& Lambkin, K. Middle Triassic orthopteroid (Titanoptera) insect from the Esk Formation at Wivenhoe Dam. Memoirs. Queensl. Mus.33, 258 (1992).

14 Yin, A. \& Nie, S. An indentation model for the North and South China collision and the development of the Tan-Lu and Honam fault systems, eastern Asia. Tectonics12, 801-813 (1993).

15 Ree, J.-H., Cho, M., Kwon, S.-T. \& Nakamura, E. Possible eastward extension of Chinese collision belt in South Korea: the Imjingang belt. Geology24, 1071-1074 (1996).

16 Chough, S., Kwon, S.-T., Ree, J.-H. \& Choi, D. Tectonic and sedimentary evolution of the Korean peninsula: a review and new view. Earth-Sci. Rev.52, 175-235 (2000).

17 Kwon, S. et al. Evidence for Permo-Triassic collision in far east Asia: the Korean collisional orogen. Earth. Planet. Sci. Lett.279, 340-349 (2009).

18 Oh, C. W. A new concept on tectonic correlation between Korea, China and Japan: histories from the late Proterozoic to Cretaceous. Gondwana Res.9, 47-61 (2006).

19 Zhai, M. et al. Linking the Sulu UHP belt to the Korean Peninsula: Evidence from eclogite, Precambrian basement, and Paleozoic sedimentary basins. Gondwana Res.12, 388-403 (2007).

20 Chang, K.-H. \& Zhao, X. North and South China suturing in the east end: What happened in Korean Peninsula? Gondwana Res.22, 493-506 (2012).

21 Egawa, K. \& Lee, Y. I. Jurassic synorogenic basin filling in western Korea: Sedimentary response to inception of the western Circum-Pacific orogeny. Basin Res.21, 407-431 (2009).

22 Lee, S.-W. \& Chung, G.-S. Facies Analysis of the Early Mesozoic Hajo Formation in the Chungnam Basin, Boryeong, Korea. J. Korean Ear.Sci.S.31, 18-35 (2010).

23 Kim, J. H. Sphenophyllum sp.(Sphenophyllales) newly found from Upper Triassic Baegunsa Formation, Nampo Group, Korea. Bull. Nat. Sci. Mus. Series C15, 93-96 (1989). 
24 Kim, J. H. \& Kimura, T. Lobatannularia nampoensis (Kawasaki) Kawasaki from the Upper Triassic Baegunsa Formation, Nampo Group, Korea. P. Jpn. Acad, Series B64, 221-224 (1988).

25 Kim, J.-H. \& Lee, G.-H. Fossil Conchostraca from the Amisan Formation of the Nampo Group, Korea. J. Korean Ear.Sci.S.36, 181-189 (2015).

26 Lee, H., Park, S.-I., Choi, T. \& Sim, M. S. Post-collisional denudation of an orogenic belt traced from geochronological and bulk-rock geochemical records of the western Korean Peninsula. Int. Geol. Rev.63, 87-108 (2021).

27 Park, S.-I., Kwon, S., Kim, S. W., Hong, P. S. \& Santosh, M. A Mesozoic orogenic cycle from post-collision to subduction in the southwestern Korean Peninsula: New structural, geochemical, and chronological evidence. J. Asian Ear. Sci.157, 166-186 (2018).

28 Park, S.-I. et al. Inversion of two-phase extensional basin systems during subduction of the PaleoPacific Plate in the SW Korean Peninsula: Implication for the Mesozoic "Laramide-style" orogeny along East Asian continental margin. Geosci. Front.10, 909-925 (2019).

$29 \mathrm{Koh}, \mathrm{H}$. Tectonic implication of the Mungyeong-Jeongseon tectonic line, the Yeongweol Nappe and the Bansong Group in the Ogcheon belt. Mesozoic Crustal Evolution of Northeast Asia, Korean Institute of Geosci. and Mineral Resources, 228-259 (2006).

30 Jeon, H., Cho, M., Kim, H., Horie, K. \& Hidaka, H. Early Archean to Middle Jurassic evolution of the Korean Peninsula and its correlation with Chinese cratons: SHRIMP U-Pb zircon age constraints. J. Geol.115, 525-539 (2007).

31 Egawa, K. \& Itoh, Y. East Asia-wide flat slab subduction and Jurassic synorogenic basin evolution in west Korea. Mechanism of sedimentary basin formation-Multidisciplinary approach on active plate margins, 63-81 (2013).

32 Egawa, K. \& Lee, Y. I. K-Ar dating of illites for time constraint on tectonic burial metamorphism of the Jurassic Nampo Group (West Korea). Geosci. J.15, 131-135 (2011).

33 Kee, W.-S. et al. 1:1,000,000 Geologic Map of Korea. (Korea Institute of Geoscience and Mineral Resources, Daejeon, 2019).

34 Park, S.-I. \& Noh, J. Jangsan fault: Evidence of structural inversion of the Chungnam Basin. J. Geol. S. Korea51, 451-469 (2015).

35 Kobayashi, T. A sketch of Korean geology. American Journal of Science 5, 585-606 (1933).

36 Choi, D. Geology and tectonic evolution of the Korean Peninsula. Seoul: Seoul National University Press (in Korean with English summary) (2014). 
37 Choi, H., Kim, D. \& Seo, H. Stratigraphy, depositional environment and basin evolution of the daedong strata in the chungnam coalfield: KR-87-(B)-3. Korea Institute of Energy and Resources, 97p (in Korean with English abstract) (1987).

38 Yang, S. The Lower Mesozoic strata. Geology of Korea. Sigma Press, Seoul, Korea, 206-226 (1999).

39 Cluzel, D. Formation and tectonic evolution of early Mesozoic intramontane basins in the Ogcheon belt (South Korea): a reappraisal of the Jurassic "Daebo orogeny". J. Se. Asian Ear. Sci.7, 223-235 (1992).

40 Kim, B. Geological and paleontological studies of Chungnam Coalfield. J. Geol. S. Korea12, 124-143 (1976).

$41 \mathrm{Kim}, \mathrm{J}$. H. Three new Equisetites species found from the Upper Triassic Amisan Formation, Nampo Group, Korea. J. Palaeol. S. Korea6, 91-99 (1990).

$42 \mathrm{Kim}$, J. New fossil plants from the Nampo Group (Lower Mesozoic), Korea. Geosci. J.5, 173-180 (2001).

43 Kim, J.-H., Kim, H.-S., Lee, B.-J., Kim, J.-M. \& Lee, H.-K. A new species of Leptostrobus from the Upper Triassic Amisan Formation of the Nampo Group in Korea. J. Korean Ear. Sci.S.23, 30-37 (2002).

$44 \mathrm{Kim}$, J.-H. \& Roh, H.-S. Organ fossils of Neocalamitescarrerei from the Amisan Formation of the Nampo Group, Korea. J. Korean Ear.Sci.S.29, 466-473 (2008).

45 Kimura, T. \& Kim, B.-K. Geological age of the Daedong flora in the Korean Peninsula and its phytogeographical significance in Asia. P. Jpn. Acad, Series B60, 337-340 (1984).

46 Kim, J. H., Lee, C. K. \& Choi, D. Y. Margaritifera cf. isfarensis (Chernishev) from the Amisan Formation, Nampo Group, Korea. J. Geol. S. Korea51, 357-362 (2015).

47 Nam, K. S. \& Kim, J.-H. Occurrence of the fossil Mesopsychedobrokhotovae in the Late Triassic Amisan Formation, Nampo Group, Korea and its geological implication. J. Korean Ear. Sci.S. 35, 161-167 (2014).

48 Nam, K. S., Wang, Y., Ren, D., Kim, J. H. \& Szwedo, J. An extraordinary palaeontinid from the Triassic of Korea and its significance. Sci.Rep.7, 1-6 (2017).

49 Kim, S.-H., Lee, Y.-N., Park, J.-Y., Lee, S. \& Lee, H.-J. The first record of redfieldiiform fish (Actinopterygii) from the Upper Triassic of Korea: Implications for paleobiology and paleobiogeography of Redfieldiiformes. Gondwana Res.80, 275-284 (2020).

$50 \mathrm{Kim}, \mathrm{J} . \mathrm{H}$. Species diversity and leaf form of ginkgoaleans from the Mesozoic and Cenozoic strata in Korea. J. Korean Ear. Sci.S. 30, 1-9 (2009). 
$51 \mathrm{Kim}, \mathrm{J} . \mathrm{H}$. Weltrichia sp. from the Late Triassic Amisan Formation of Nampo Group, Korea. J. Korean Ear. Sci.S. 34, 402-406 (2013).

52 Lee, W.-K., Kim, Y.-S., Kim, C.-Y., Kim, H.-S. \& Kim, J.-H. A Revision of Mesozoic Equisetales Annuriopsisbunkeiensis Kimura et Kim from the Amisan Formation of Nampo Group, Korea. J. Korean Ear. Sci.S. 25, 32-38 (2004).

53 Schneider, C. A., Rasband, W. S. \& Eliceiri, K. W. NIH Image to ImageJ: 25 years of image analysis. Nat.Methods9, 671-675 (2012).

54 Béthoux, O. \& Nel, A. Venation pattern and revision of Orthoptera sensu nov. and sister groups. Phylogeny of Palaeozoic and Mesozoic Orthoptera sensu nov. Zootaxa96, 1-88 (2002).

55 Desutter-Grandcolas, L. et al. 3-D imaging reveals four extraordinary cases of convergent evolution of acoustic communication in crickets and allies (Insecta). Sci. Rep.7, 1-8 (2017).

56 Gorochov, A. The first representative of the suborder Mesotitanina from the Paleozoic and notes on the system and evolution of the order Titanoptera (Insecta: Polyneoptera). Paleontol. J.41, 621-625 (2007).

57 Park, T.-Y. S. et al. Brain and eyes of Kerygmachela reveal protocerebral ancestry of the panarthropod head. Nat.Commun.9, 1-7 (2018).

58 Kim, D.-Y., Lee, M., Nam, G.-S. \& Park, T.-Y. S. The first orthopteran fossils from the Lower Cretaceous (Albian) Jinju Formation of Korea: ethological implications for elcanids. Cretaceous Res.125, 104843 (2021).

59 Scotese, C. R. An Atlas of Phanerozoic Paleogeographic Maps: The Seas Come In and the Seas Go Out. Annu. Rev. Ear. Planet. Sci.49 (2021).

60 Retallack, G. J., Veevers, J. J. \& Morante, R. Global coal gap between Permian-Triassic extinction and Middle Triassic recovery of peat-forming plants. Geol. S. Am. Bull.108, 195-207 (1996).

61 Shao, L. et al. Sequence stratigraphy, paleogeography, and coal accumulation regularity of major coalaccumulating periods in China. Int. J. Coal Sci.Technol.7, 240-262 (2020).

62 Dai, S. et al. Recognition of peat depositional environments in coal: A review. Int. J. Coal Geol.219, 103383 (2020).

63 Han, R., Ree, J.-H., Cho, D.-L., Kwon, S.-T. \& Armstrong, R. SHRIMP U-Pb zircon ages of pyroclastic rocks in the Bansong Group, Taebaeksan Basin, South Korea and their implication for the Mesozoic tectonics. Gondwana Res.9, 106-117 (2006).

64 Ree, J. H., Kwon, S. H., Park, Y., Kwon, S. T. \& Park, S. H. Pretectonic and posttectonic emplacements of the granitoids in the south central Okchon belt, South Korea: Implications for the timing of strike-slip 
shearing and thrusting. Tectonics20, 850-867 (2001).

65 Yang, W., Wang, M., Zheng, D. \& Du, Y. Late Triassic sedimentary record from the Nanzhao Basin and implications for the orogeny in the Qinling Orogenic Belt, central China. J. Asian Ear. Sci.166, 120-135 (2018).

66 Yin, H.-f. Triassic biostratigraphy of China. Biostratigraphy of China (2003).

67 Li, F. et al. Analysis of Sedimentary Environment and Coal-forming Pattern of Anyuan Formation in Pingxiang Depression. Sci. Technol. Eng.2016, 23 (2016).

68 Zhang, C., Cui, L., Shao, K., Shao, L. \& Hu, Y. The sedimentary environment and palaeogeographic characteristics of the Late Triassic epoch in Shaoshan Coal Field of Hunan Province. Procedia Env. Sci.12, 499-504 (2012).

69 Cheng, Y.-Q., Geng, S.-F., Xie, L.-Z., Ding, X.-Z. 1: 4,000,000 Geological Map of China. (Geological Publishing House, Beijing, 2002).

70 Oh, C. W. et al. First finding of eclogite facies metamorphic event in South Korea and its correlation with the Dabie-Sulu collision belt in China. J. Geol.113, 226-232 (2005).

71 Oh, C. W., Imayama, T., Jeon, J. \& Yi, K. Regional Middle Paleozoic metamorphism in the southwestern Gyeonggi Massif, South Korea: its implications for tectonics in Northeast Asia. J. Asian Ear. Sci.145, 542564 (2017).

72 Kim, S. W., Kwon, S., Santosh, M., Williams, I. S. \& Yi, K. A Paleozoic subduction complex in Korea: SHRIMP zircon U-Pb ages and tectonic implications. Gondwana Res.20, 890-903 (2011).

$73 \mathrm{Kim}, \mathrm{S}$. W. et al. Early to Middle Paleozoic tectonometamorphic evolution of the Hongseong area, central western Korean Peninsula: Tectonic implications. Gondwana Res.47, 308-322 (2017).

74 Zhao, L., Zhai, M., Santosh, M. \& Zhou, X. Early Mesozoic retrograded eclogite and mafic granulite from the Badu Complex of the Cathaysia Block, South China: Petrology and tectonic implications. Gondwana Res.42, 84-103 (2017).

$75 \mathrm{Lu}, \mathrm{K}$. et al. Geochronological and geochemical data of paragneiss and amphibolite from the Chencai Group in South China: implications for petrogenesis and tectonic significance. Geol. J.55, 6823-6840 (2020).

76 Qian, J., Yin, C., Zhang, J. \& Jin, X. Early Paleozoic high-temperature metamorphism of garnet amphibolite in the Longyou area, Cathaysia Block of South China: P-T path and tectonic implications. J. Asian Ear. Sci.213, 104744 (2021). 
77 Zhao, L., Zhai, M., Zhou, X., Santosh, M. \& Ma, X. Geochronology and geochemistry of a suite of mafic rocks in Chencai area, South China: implications for petrogenesis and tectonic setting. Lithos236, 226244 (2015).

78 Zhao, L., Cui, X., Zhai, M., Zhou, X. \& Liu, B. Emplacement and metamorphism of the mafic rocks from the Chencai terrane within the Cathaysia Block: Implications for the Paleozoic orogenesis of the South China Block. J. Asian Ear. Sci.173, 11-28 (2019).

79 Wang, Y. et al. Early Neoproterozoic ( $840 \mathrm{Ma})$ slab window in South China: Key magmatic records in the Chencai Complex. Precambrian Res.314, 434-451 (2018).

$80 \mathrm{Li}, \mathrm{L}$. , Lin, S., Li, J., He, J. \& Ge, Y. Zircon U-Pb ages and Hf isotope compositions of the Chencai migmatite, central Zhejiang Province, South China: constraints on the early Palaeozoic orogeny. Geol. Mag.155, 1377-1393 (2018).

$81 \mathrm{Li}, \mathrm{J}$. et al. New insights into Phanerozoic tectonics of South China: Early Paleozoic sinistral and Triassic dextral transpression in the east Wuyishan and Chencai domains, NE Cathaysia. Tectonics36, 819-853 (2017).

$82 \mathrm{Xu}$, Y.-J., Cawood, P. A. \& Du, Y.-S. Intraplate orogenesis in response to Gondwana assembly: Kwangsian orogeny, South China. Am. J. Sci.316, 329-362 (2016).

$83 \mathrm{Li}, \mathrm{Z}$. -X. et al. Magmatic and metamorphic events during the early Paleozoic Wuyi-Yunkai orogeny, southeastern South China: New age constraints and pressure-temperature conditions. Bull.122, 772-793 (2010).

84 Imayama, T., Oh, C. W., Jeon, J. \& Yi, K. Neoproterozoic and middle Paleozoic geological events in the eastern Wolhyeonri complex of the southwestern Gyeonggi Massif, South Korea, and their tectonic correlations in northeastern Asia. Lithos382, 105923 (2021).

85 Wang, F. et al. Tectonothermal history of the NE Jiangshan-Shaoxing suture zone: Evidence from 40Ar/39Ar and fission-track thermochronology in the Chencai region. Precambrian Res.264, 192-203 (2015).

86 Lyu, P. et al. The nature of Early Palaeozoic Kwangsian orogenic event in the South China Block: constraints from detrital zircons in Cambrian strata. Int.Geol. Rev. 1-14 (2020).

87 Zhou, b. X., Sun, T., Shen, W., Shu, L. \& Niu, Y. Petrogenesis of Mesozoic granitoids and volcanic rocks in South China: a response to tectonic evolution. Episodes29, 26 (2006).

88 Gao, W., Wang, Z., Li, L. \& Tan, Y. Petrogenesis and tectonic implications of Triassic A-type granites in southeastern China: insights from zircon $\mathrm{U}-\mathrm{Pb}-\mathrm{Hf}$ isotopic and whole-rock geochemical compositions of the Luoguyan and Guiyantou granites in northwestern Fujian Province. Int. Geol. Rev.61, 224-239 (2019). 
89 Wang, Y., Zhang, Y., Fan, W. \& Peng, T. Structural signatures and 40Ar/39Ar geochronology of the Indosinian Xuefengshan tectonic belt, South China Block. J. Struct. Geol.27, 985-998 (2005).

90 Wang, Y., Fan, W., Guo, F., Peng, T. \& Li, C. Geochemistry of Mesozoic mafic rocks adjacent to the Chenzhou-Linwu fault, South China: implications for the lithospheric boundary between the Yangtze and Cathaysia blocks. Int. Geol. Rev.45, 263-286 (2003).

91 Wang, B. et al. Phanerozoic multistage tectonic rejuvenation of the continental crust of the cathaysia block: insights from structural investigations and combined zircon U-Pb and mica 40Ar/39Ar geochronology of the granitoids in southern Jiangxi province. J. Geol.122, 309-328 (2014).

92 Shu, L., Wang, B., Cawood, P. A., Santosh, M. \& Xu, Z. Early Paleozoic and Early Mesozoic intraplate tectonic and magmatic events in the Cathaysia Block, South China. Tectonics34, 1600-1621 (2015).

93 Sun, Y., Ma, C., Liu, Y. \& She, Z. Geochronological and geochemical constraints on the petrogenesis of late Triassic aluminous A-type granites in southeast China. J. Asian Ear. Sci.42, 1117-1131 (2011).

$94 \mathrm{Li}$, W., Ma, C., Liu, Y. \& Robinson, P. T. Discovery of the Indosinian aluminum A-type granite in Zhejiang Province and its geological significance. Sci. China Ear. Sci.55, 13-25 (2012).

$95 \mathrm{Mao}$, J. et al. The Indosinian collision-extension event between the South China Block and the PalaeoPacific plate: evidence from Indosinian alkaline granitic rocks in Dashuang, eastern Zhejiang, South China. Lithos172, 81-97 (2013).

$96 \mathrm{Li}, \mathrm{Z} .-\mathrm{X}$. et al. Magmatic switch-on and switch-off along the South China continental margin since the Permian: Transition from an Andean-type to a Western Pacific-type plate boundary. Tectonophysics532, 271-290 (2012).

97 Tao, N. et al. Post-250 Ma thermal evolution of the central Cathaysia Block (SE China) in response to flat-slab subduction at the proto-Western Pacific margin. Gondwana Res.75, 1-15 (2019).

98 Cho, D.-L., Lee, S. R. \& Armstrong, R. Termination of the Permo-Triassic Songrim (Indosinian) orogeny in the Ogcheon belt, South Korea: Occurrence of ca. 220 Ma post-orogenic alkali granites and their tectonic implications. Lithos105, 191-200 (2008).

99 Park, K.-H., Song, Y.-S. \& Seo, J. U-Pb Geochronology of the Triassic foliated granite distributed in the eastern Sancheong area, SW Yeongnam Massif, Korea and its Implications. J. Petrol. S. Korea27, 223-233 (2018).

100 Kim, S. W. et al. Geotectonic framework of Permo-Triassic magmatism within the Korean Peninsula. Gondwana Res.20, 865-889 (2011).

$101 \mathrm{Kim}, \mathrm{S}$. W. et al. The middle permian to triassic tectono-magmatic system in the southern Korean Peninsula. Gondwana Res. (2020). 
102 Williams, I. S., Cho, D.-L. \& Kim, S. W. Geochronology, and geochemical and Nd-Sr isotopic characteristics, of Triassic plutonic rocks in the Gyeonggi Massif, South Korea: constraints on Triassic post-collisional magmatism. Lithos107, 239-256 (2009).

103 Lee, B. C., Jo, H. J., Lee, S. H. \& Jeong, Y.-J. Geochronology and petrogenesis of the Late Triassic Atype granitoids in the Yeongnam Massif and its implication for Late Triassic geodynamics of northeast Asia. Lithos386, 106018 (2021).

\section{Figures}

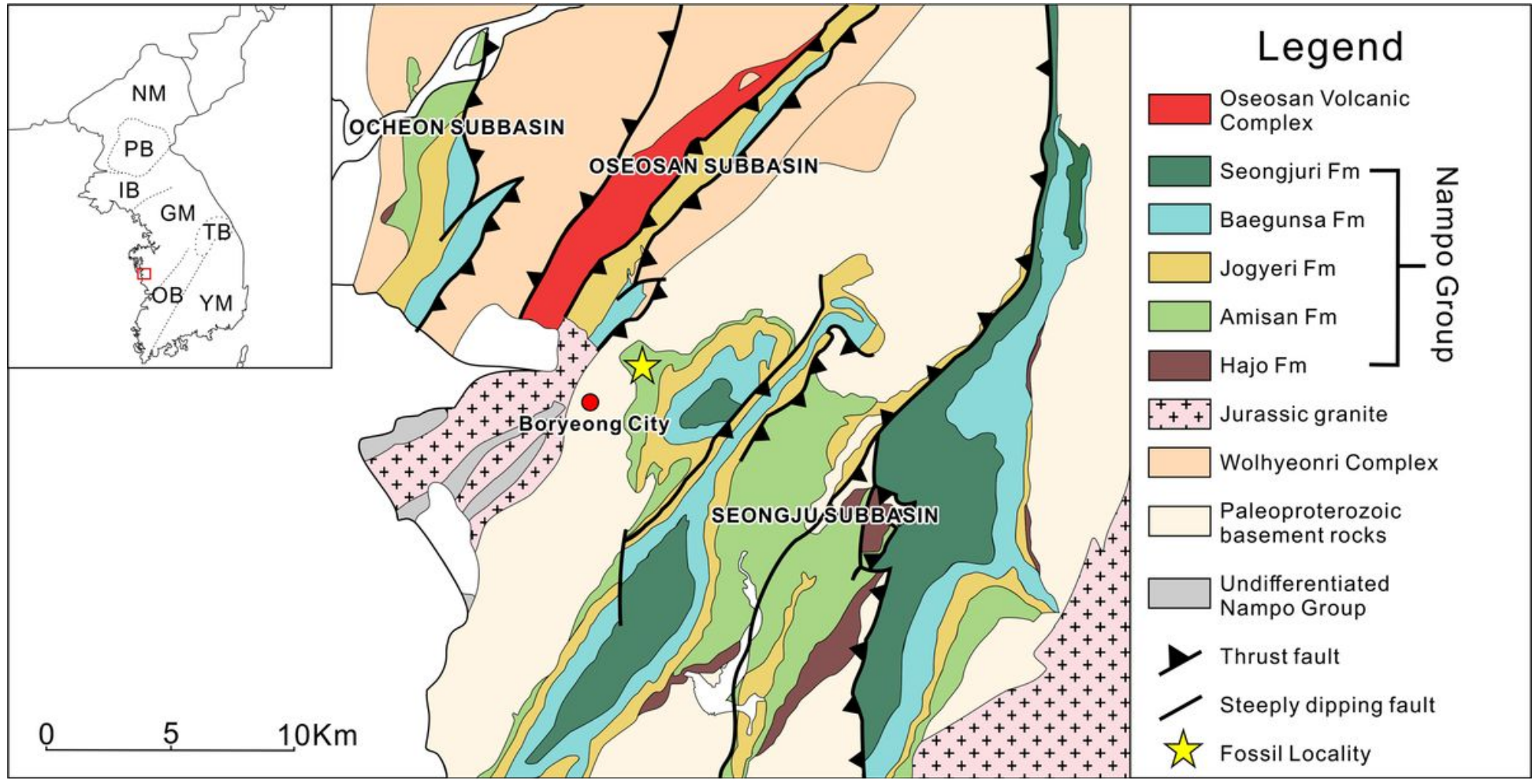

Figure 1

Geological map of the study area with the location in the Korean Peninsula (modified from ref[21, 28, 33]). The star represents the Myeongcheon Section, the fossil locality. NM, Nangrim Massif; PB, Pyeongan Basin; IB, Imjingang Belt; GM, Gyeonggi Massif; TB, Taebaeksan Basin; OB, Okcheon Basin; YM, Yeongnam Massif. 

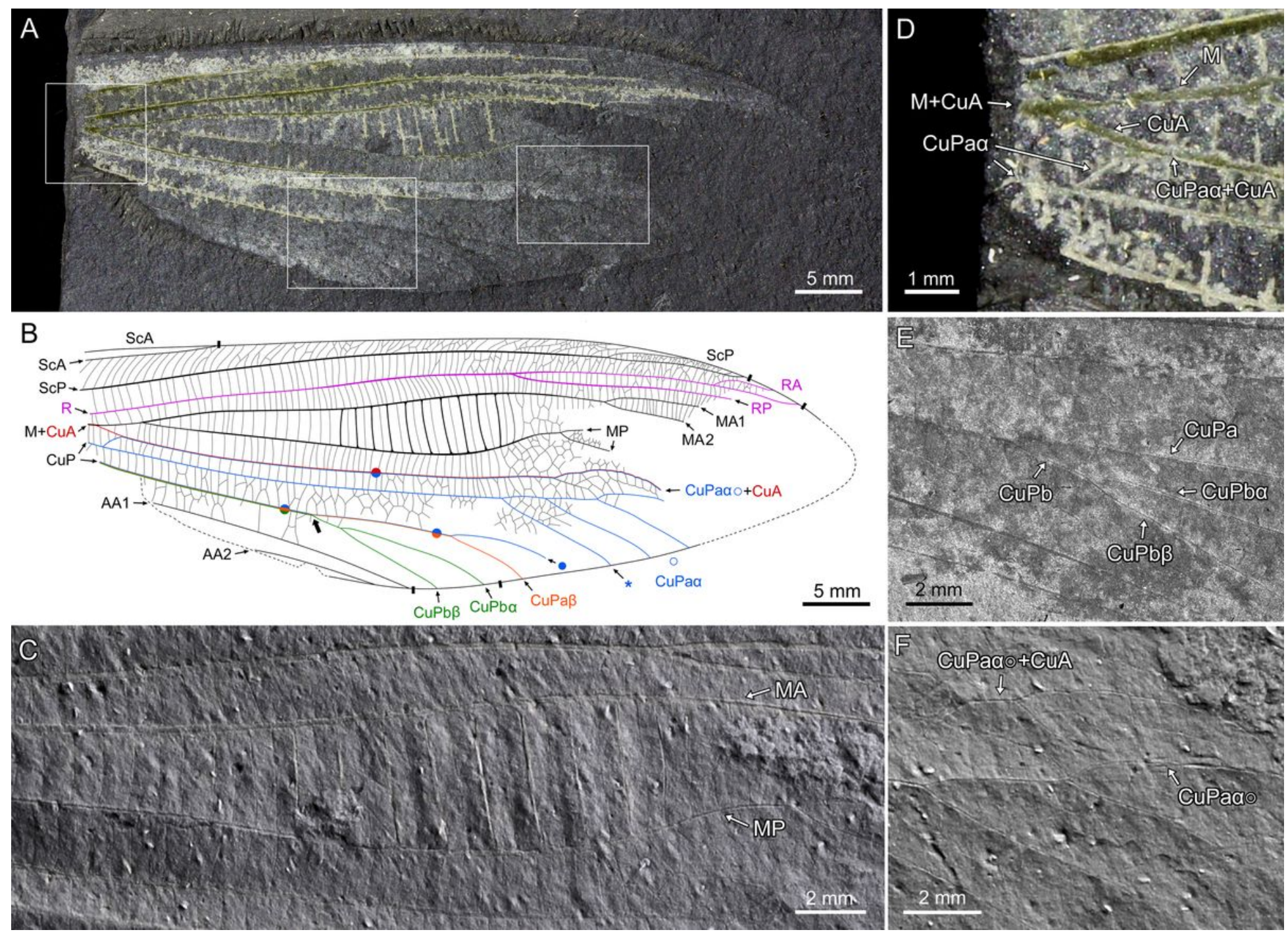

\section{Figure 2}

Holotype of Magnatitan jongehoni gen. et sp. nov.GNUE112001. (A) Overview of the specimen. The rectangle areas from left to right are zoomed up in $D, E$, and F, respectively. (B) The interpretive drawing. (C) A PTM image, showing the distinctive cross-veins developed between MA and MP. (D) Magnified image of the proximal part of the forewing. (E) A silicon elemental map from the WDS analysis, showing details around the division of $\mathrm{CuPb}$. F, A PTM image showing $\mathrm{CuA}+\mathrm{CuPaa}^{\circ}$ and $\mathrm{CuPaa}^{\circ}$, and the crossveins in between. 


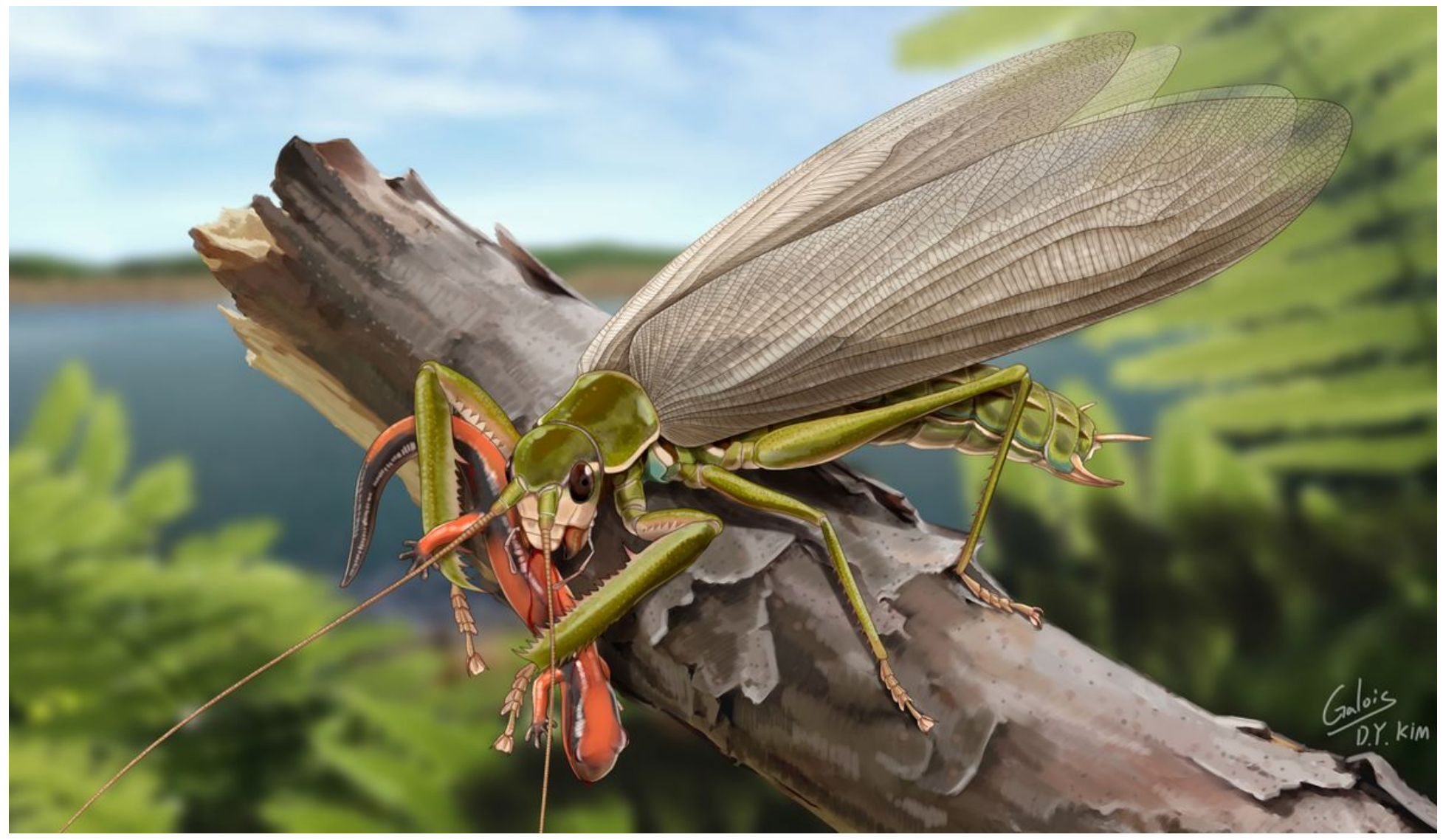

\section{Figure 3}

Artistic reconstruction of Magnatitan jongheoni gen. et sp. nov., preying upon a small amphibian (artwork by Do-Yoon Kim).

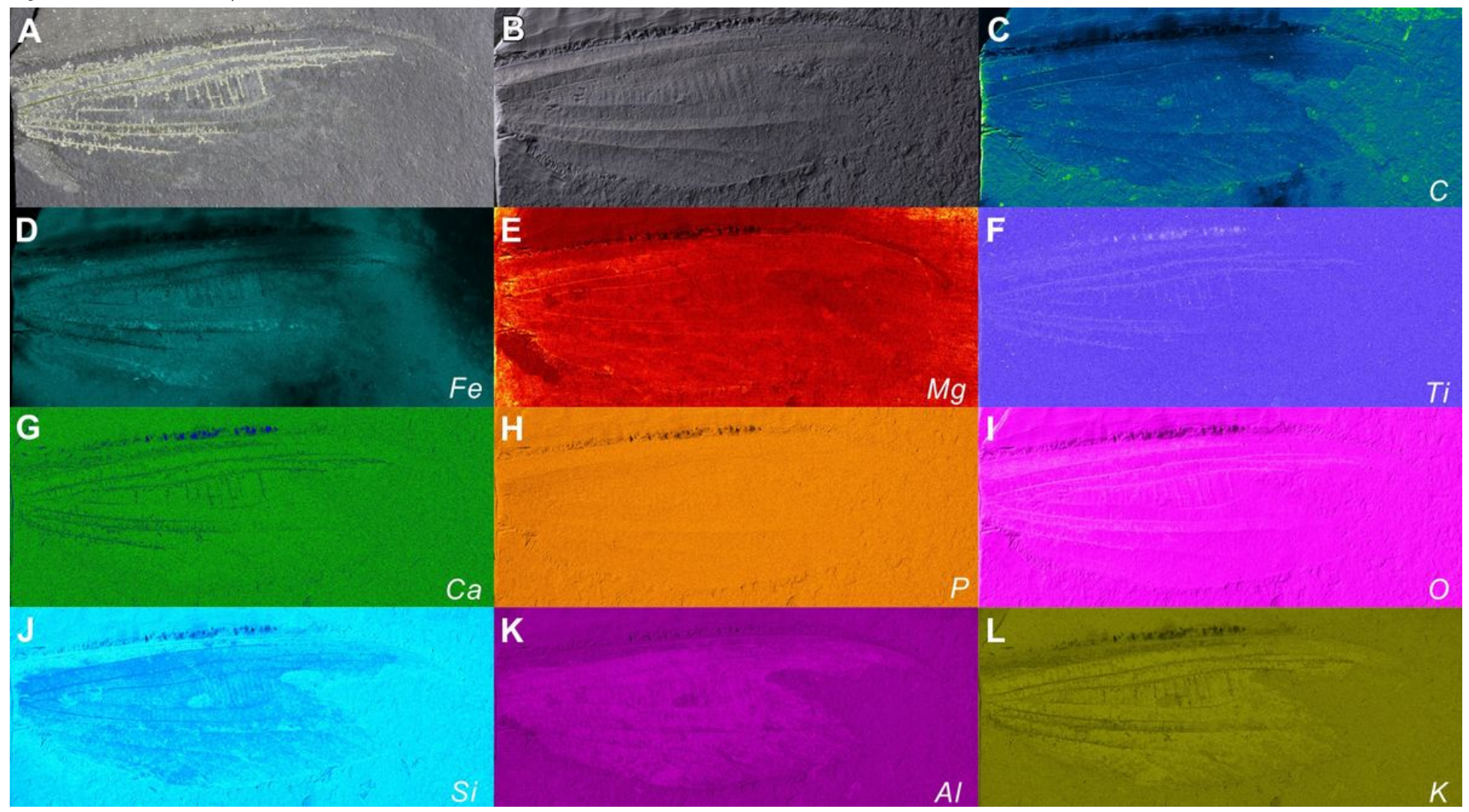




\section{Figure 4}

Wavelength dispersive spectrometer (WDS) and energy dispersive spectrometer (EDS) images of the wing of Magnatitan jongheoni gen. et sp. nov. from the Amisan Formation. (A-B) WDS elemental maps of carbon and iron, respectively. (C-F) EDS elemental maps of silicon (C), oxygen (O), aluminium ( $\mathrm{Al}$, ) and potassium (K).

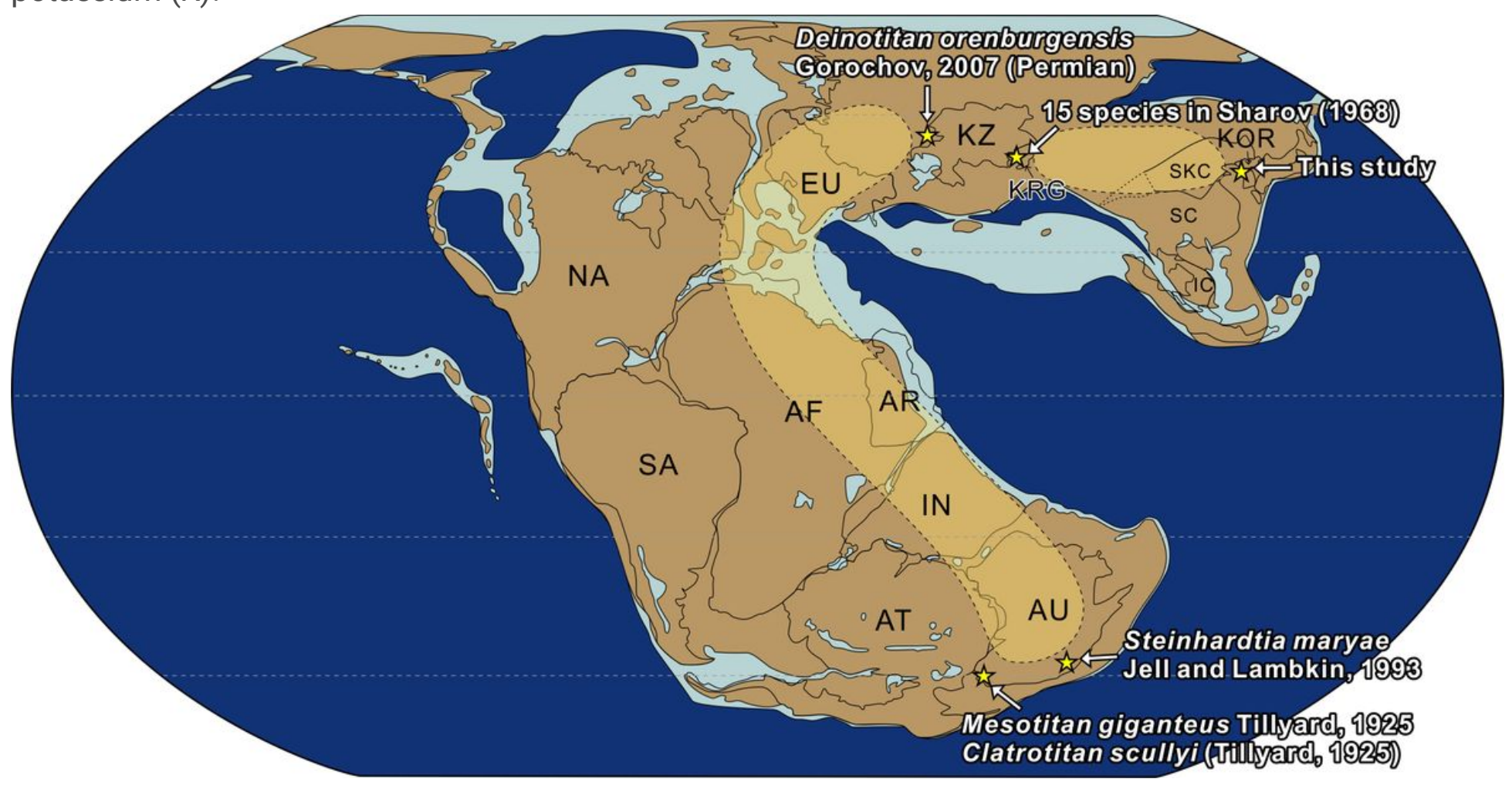

Figure 5

A paleogeographic map of the Late Triassic with the occurrences of titanopterans (stars) and the inferred areas with possible distributions (marked by dotted lines). The map modified from ref(59). AF, Africa; AR, Arabia; AT, Antarctica; AU, Australia; EU, Europe; IC, Indochina; IN, India; KOR, Korea; KRG, Kyrgyzstan; KZ, Kazakhstan; NA, North America; SA, South America; SC, South China; SKC, Sino-Korean (North China) Craton. 


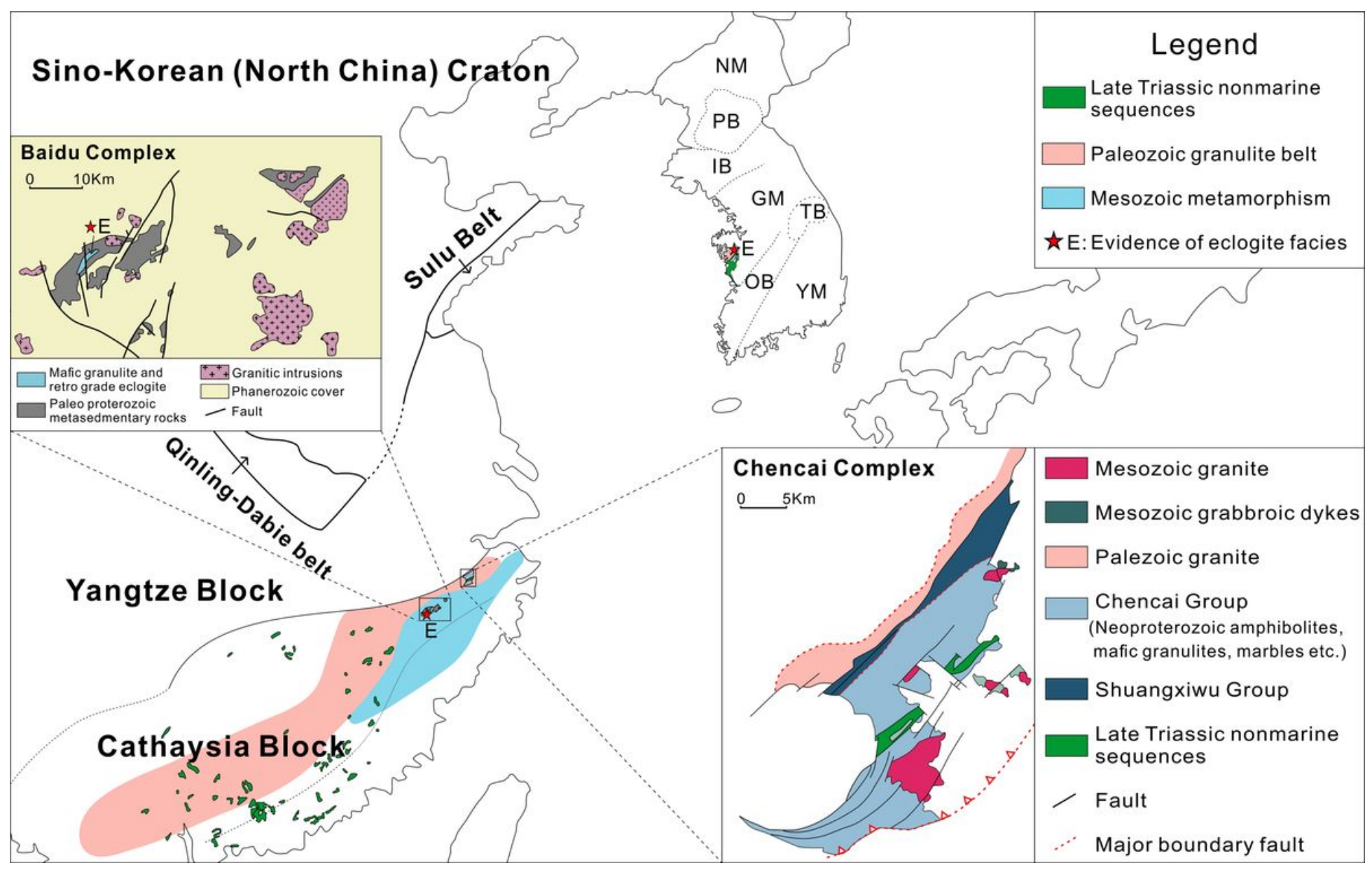

Figure 6

Simplified tectonic map of northeast Asia with major tectonic boundaries in China and the Korean Peninsula. The geologic features of the Baidu Complex and the Chencai Complex at northeast Cathaysia Block are represented by zoom ups. Similar occurrences of petrologic features and the Late Triassic nonmarine sedimentary sequences point toward the tectonic linkage between the northeastern Cathaysia Block and the southwestern Korean Peninsula (see text). Modified from ref $(69,74,80)$. NM, Nangrim Massif; PB, Pyeongan Basin; IB, Imjingang Belt; GM, Gyeonggi Massif; TB, Taebaeksan Basin; OB, Okcheon Basin; YM, Yeongnam Massif. 